\title{
Evaluations of Parenting by Same-Sex vs Different- Sex Couples among Heterosexual University Students: Experimental Between-Subjects Vignette Design Study
}

DOI: $10.5613 /$ rzs.49.2.6

UDK: 316.644-055.2-057.875(497.521.2):316.36

316.644-055.2-057.875(497.521.2):316.362.34-055.52-055.62

Izvorni znanstveni rad

Primljeno: 5. 4. 2019.

\author{
Mateo ŠTRBIĆ (D), Tomislav JELEKOVIĆ (D), Dora POPOVIĆ (D), \\ Marija BRAJKOVIĆ (D), Petra ŽUKINA (D) \\ students (Division of Psychology, University Department of Croatian studies, \\ University of Zagreb, Croatia) \\ mateo.strbic@gmail.com, tomislavjelekovic.tj@gmail.com,dora.popovic123@ \\ gmail.com,marijabrajkovic95@gmail.com, petra.zukinax@gmail.com
}

\section{Marina ŠTAMBUK}

Department of Management and Rural Entrepreneurship, Faculty of Agriculture,

University of Zagreb, Croatia

mstambuk@agr.hr

\section{ABSTRACT}

Despite the decline in prejudice towards LGBT people, the issue of parenthood is still controversial with negative attitudes towards LGBT parents being openly expressed. This study aimed to examine attitudes towards parenting by same-sex couples using a vignette design. Parenting condition (parent's negative vs positive reaction), active parent's gender (mother vs father) and family composition (different-sex vs same-sex couple) were varied to test differences in the evaluations of parenting, child behaviour, family environment, social distance and willingness to grant rights. 392 heterosexual and cisgender students from the University of Zagreb ( $87 \%$ female, $13 \%$ male), aged 18 to 37 , participated in an online study. After reading one of the eight vignettes, participants evaluated parenting, child behaviour, family environment, social distance and rights of the family described in the vignette. The results showed that parenting and family environment were evaluated as better, and participants were less convinced that the child's behaviour is the result of parents' relationship in the positive parenting condition than in the negative. Social distance was lower towards parents in the positive parenting condition than in the negative and - unexpectedly - towards same-sex in comparison to different-sex couples. Participants were more inclined to grant family rights to parents from the positive than to those from the negative parenting condition. Although other results suggested unbiased attitudes towards same-sex couples' parenting, participants were less inclined to grant same-sex couples family rights in comparison to different- 
sex couples. The findings reflect an important mechanism underlying the stability of prejudice - a resistance towards generalising attitudes from individual cases to a group. This can be used in efforts to confront prejudice against parenting among LGBT people.

Keywords: $\quad$ same-sex couples, different-sex couples, parenting, child behaviour, social distance, family rights

\section{INTRODUCTION}

While negative attitudes towards lesbian, gay, bisexual and trans (LGBT) people as parents still exist, options for them to become parents are increasingly becoming available in the West (Baumle and D'Lane, 2017). In Croatia, the legal framework does not allow same-sex life partners to become parents via adoption, foster care or assisted reproductive technologies (Assisted Reproductive Technologies Act, 2012; Foster Care Act, 2018) and the public discourse about parenthood rights for LGBT people is often accompanied by hate speech, prejudice, and justification of discrimination (e.g. Peruzzi, 2015). However, even in a rather homophobic social context such as present-day Croatia (Takács and Szalma, 2013), there is evidence of a decline in the negative attitudes towards same-sex parents at a micro level, in real-life situations. For example, lesbian mothers report positive experiences in their immediate social surroundings such as neighbourhood, kindergarten, school or medical care (Maričić et al., 2016).

In order to further our knowledge about reactions to same-sex parents and their children, it would be valuable to empirically test reactions to these families in different scenarios. Using a vignette design provides an opportunity to approach that goal by studying reactions to a hypothetical but specific event. Such an approach bears more ecological validity in comparison to a classical survey. Previous research in Croatia was mostly conducted using correlational design and has been focussed on traditional and modern prejudice about gays and lesbians as well as support for their rights (e.g. Huić, Jugović and Kamenov, 2015; Kamenov, Huić and Jelić, 2019). In order to complement the previous findings, this study aimed to research the evaluations of same-sex parenting and child's behaviour among heterosexual and cisgender ${ }^{1}$ students by varying parent's behaviour towards the child, active parent's gender and family composition (different-sex vs same-sex couple), using a vignette study design.

$1 \quad$ Cisgender is a term describing people whose gender identity matches the sex they were assigned at birth. 


\subsection{Attitudes toward LGBT parenthood}

Globally, negative attitudes towards LGBT people are decreasing over time (Carroll and Robotham, 2017). However, this does not mean that prejudices are disappearing. Overt prejudices are rather being replaced by more implicit expressions such as denial of discrimination, less willingness to grant rights and the belief that LGBT people have all the rights they need (e.g. Morrison, Morrison and Franklin, 2009). Despite the decline in the general prejudice against LGBT people, the issue of parenthood is still highly controversial and attitudes towards LGBT people as unfit parents are rather openly expressed. In general, men show more negative attitudes toward same-sex parenting and marriage than women (loverno et al., 2017; Moskovitz, Rieger and Roloff, 2010). Furthermore, same-sex parenting is considered immoral and it is presumed that children's wellbeing is compromised because LGBT people are considered hypersexual, parents' homo/bisexual orientation is believed to harm the development of the child's sexual and gender identity and masculinity is stereotypically anticipated in lesbian mothers and considered the cause of inappropriate parent-child interactions (Clarke, 2001; Patterson, 2000). Altogether, these findings suggest that participants negatively evaluate the family environment and dynamics in families with LGBT parents. These stereotypes encourage negative attitudes and expectations about LGBT people's parenting skills and competences (Ball, 2012).

Along with negative evaluations, prejudice can be expressed in terms of social distance. Those who hold prejudice will exhibit larger affectionate distance, i.e. less desire and intention to participate in activities with individuals who belong to a certain out-group (Bogardus, 1925). Previous research showed that larger social distance towards gays/lesbians is related to higher levels of essentialist beliefs about the social and psychological differences between genders (Agadullina, Lovakov and Malysheva, 2018), which is further related to an increased tendency to discriminate (Huić, Jelić and Kamenov, 2018), as well as to support boundary-enhancing legislation, policies and social services (Roberts et al., 2017).

\subsection{Attributions of the child behaviour}

According to the attribution model (Wiener, 1985), each behaviour is evaluated on three dimensions: locus (internal vs external), stability (constant vs variable) and controllability (under vs out of person's control). These attributions are interesting to research in the context of a child's behaviour because they can be interpreted differently depending on the child's developmental level. If a toddler shows undesirable behaviour, that could be attributed to the usual phase of autonomy search 
(Erikson, 1959), while the same behaviour in older children could be interpreted in more negative terms. Also, the lack of knowledge about children's behaviour can shape the observers' evaluations in various directions - attributing the cause of the behaviour to the parents and their relationship, the child, developmental changes, situation, etc. Massey (2007) used this ambiguity to test implicit prejudices towards same-sex parents. The author expected that participants would consider a child's undesirable behaviour a result of the family situation if the parents were a same-sex couple, but if the parents were a different-sex couple the same behaviour would be considered age-appropriate. Unexpectedly, participants evaluated the behaviour of same-sex parents' children as more age-appropriate than the same behaviour of different-sex parents' children. Along with being rather liberal, Massey's participants could have formed positive attitudes towards the children of same-sex parents considering the prejudice and specific challenges that these families must face.

\subsection{Methodological considerations and results in vignette studies}

The aforementioned study by Massey (2007) is an example of a vignette design that represents a combination between a classical experiment and a survey intended to maximise the gains from both techniques while counterbalancing their weaknesses. As traditional surveys show high external but poor internal validity, the experimental design serves as a supplement, granting better internal validity. Atzmüller and Steiner (2010) define a vignette as a short and carefully constructed description with a systematic variation of factors - person, object or situation characteristics. This variation allows for a causal interpretation of participant judgements based on vignette factors. Vignettes are particularly useful in the research on sensitive topics as they allow participants to express their response in a non-threatening way (Hughes, 1998). As with all experimental designs, three general types of vignette experiments can be distinguished: within-subjects design (the same participant is exposed to all experimental conditions), between-subjects design (each participant is only exposed to a single experimental condition) and mixed design (the combination of the two). Among research on attitudes towards LGBT-parented families, the between-subjects design is the most commonly used, i.e. each participant evaluates only one type of vignette.

Research using vignettes about LGBT parenting has not yielded consistent results and study designs differed considerably. The main differences were the social context, participants' age and crucial elements of the vignette scenes. In Massey, Merriwether and Garcia's study (2013) no significant differences in attitudes towards same-sex vs different-sex couples parenting appeared. That study 
used a student sample from the United States with the child in the vignette being a toddler and the family formation method not explicitly stated. In another study, a convenient but large community sample from Australia was used with participants aged 18 to 91 . A 16-year-old child from a previous heterosexual relationship was described in the vignette (Morse, McLaren and McLachan, 2008). In this research, participants showed less favourable attitudes towards parenting by same-sex in comparison to different-sex couples.

While in the described studies participants rated child and parent behaviour described in the vignette, another line of research used adoption scenarios and participants reported their anticipations about the parent's competence and child's development (Gato and Fontaine, 2013, 2016). These studies showed expectations of non-normative sexual and gender development of children adopted by same-sex couples as well as less favourably rated parental competence of samesex compared to different-sex couples. It is interesting to note that in a study using a similar adoption vignette (McLeod, Crawford and Zechmeister, 1999), the gay father, in comparison to the heterosexual father, was perceived as having some positive qualities (being more loving and spending more quality time with the child). However, the development of his male child was perceived as more negative and custody reassignment to grandparents as more beneficial.

The results from these studies suggest that participants are less biased when evaluating specific behaviour and family dynamics that are described in the vignette, especially younger participants in a liberal social context. At the same time, participants become increasingly biased in a negative direction when reporting on the anticipation of a child's development in same-sex parented families.

\subsection{Empirical evidence on lesbian and gay parenting}

In contrast to popular prejudices, reviews of literature show no empirically valid evidence that the children raised by gay/lesbian parents experience more harmful outcomes in comparison to the children of heterosexual parents (adams and Light, 2015; Vučković Juroš, 2017). Also, LGBT people see parenting as an important factor in their intimate relationships and a desired life goal (Downing, 2013; Costa and Tasker, 2018; Štambuk, Milković and Maričić, 2019). In all, there are more similarities than differences between same-sex and different-sex parented families (Crowl, Ahn and Baker, 2008). However, the reported differences generally favour same-sex families. For instance, one study found that gay fathers express more parental love and readiness to respond to the child's needs than heterosexual fathers (Patterson, 2000). Lesbian couples show higher parental awareness skills when compared to heterosexual couples - they are more sensitive to the child's 
needs and better cope with parenting challenges (Flaks et al., 1995). The results also show that lesbian mothers have positive mother-child relationships and their children are well-adjusted (Golombok et al., 2003).

\subsection{Study context}

The first decade and a half of the 21st century were marked by positive changes in the Croatian legislation regarding the rights of LGBT persons. The family life of same-sex couples (Same-Sex Civil Union Act, 2003; Same-Sex Life Partnership Act, 2014), gender reassignment and change of legal documents were regulated (Protocol for Medical Documents Collection and Determination of the Conditions and Prerequisites for Sex Change or Life in Different Gender Identity, 2014). Also, discrimination based on sexual orientation, gender identity, and expression was banned (Anti-Discrimination Act, 2008). However, this did not automatically reflect on other laws that relate to LGBT people. For example, same-sex life partners were included in amendments to the existing acts only after public debates (Social Welfare Act, 2017; Inheritance Act, 2019) and, as a result of the popular referendum in 2013, marriage was defined as a union between a man and a woman in the Croatian constitution.

Regarding parenthood, legal changes are much slower and prejudices against LGBT parents are frequent in public (Huić, Jugović and Kamenov, 2015), mostly as expectations of harmful development in children or, in more subtle ways, as false concerns about homophobic reactions (Jugović and Ogresta, 2017). Although the Same-Sex Life Partnership Act introduced "partner guardianship", it does not allow life partners to sign up for adoption. The Foster Care Act (2018) did not include life partners as possible foster parents. In addition, the Assisted Reproductive Technologies Act (2012) does not include lesbian couples as its beneficiaries.

Sharp divisions in opinions about LGBT parenthood are shown in the results of studies among the youth as well as the general population. When explaining their opposition to gays and lesbians as parents, emerging adults aged 22 to 30 stated their concerns about the child's wellbeing, unwillingness of society to accept families with LGBT parents, lack of the "other" gender in the child's development and a general attitude about LGBT parenthood as unnatural (Jugović and Ogresta, 2017). In research involving students (Huić, Jugović and Kamenov, 2015) and the general population (Kamenov, Huić and Jelić, 2019), the majority supported social and labour rights for lesbians and gays but were far less willing to support the rights regarding family - adoption and marriage. 


\subsection{Current study}

This study aimed to examine heterosexual and cisgender students' attitudes towards same-sex parenting in Croatia using a vignette between-subjects design. We tested differences in the evaluations of parenting, child behaviour, family environment, social distance and readiness to grant rights. In the vignettes, we varied the parenting condition (parent's negative vs positive reaction), active parent's gender (mother vs father) and family composition (different-sex vs same-sex couple).

\subsubsection{Hypotheses}

(1) Parenting condition: we expected parenting and family environment to be evaluated more negatively and child behaviour as externally attributed, social distance to be greater and participants less ready to grant rights to families in the negative than in the positive parenting condition.

(2) Active parent's gender: in line with the social expectations of women as primary caregivers, we expected that in families with mothers as active parents, mothers' parenting and family environment to be evaluated more positively and child behaviour as internally attributed in comparison to the same evaluations for fathers. We expected no difference in social distance and readiness to grant rights.

(3) Family composition: we expected parenting and family environment to be evaluated more negatively, child behaviour as externally attributed, social distance to be greater and participants less ready to grant rights to the families with samesex parents in comparison to those with different-sex parents.

(4) Interaction effects: in line with the stereotypes about mothers as those who provide comfort and fathers as those who discipline children, we expected interaction between the parenting condition and active parent's gender - mother's parenting to be evaluated more negatively in the negative parenting condition in comparison to father's in the same condition and vice versa. Regarding the possible interaction between active parent's gender and family composition, lesbians tend to be evaluated more favourably than gays (LaMar and Kite, 1998), but some studies found no differences in attitudes towards lesbians and gays as parents (Gato and Fontaine, 2013, 2016). Therefore, we did not propose a hypothesis for this interaction but rather proceeded to this analysis exploratorily. Finally, we expected interaction between the parenting condition and family composition. When compared to parenting by different-sex couples, parenting by same-sex couples is expected to be evaluated more negatively in the negative parenting condition, while in the positive parenting condition to be no effect of family composition. 


\section{METHOD}

\subsection{Participants and Procedure}

A list with contact persons for all the faculties at the University of Zagreb was constructed ahead of data collection. The questionnaire was administered via an online survey software tool (SurveyGizmo) and distributed to contact persons who shared it further to their fellow students. At the beginning of the questionnaire, it was stated that participation was voluntary, data collected anonymously and that the results would only be used for scientific purposes. The contacts of the first and the second author were provided. First, socio-demographic information was collected, after which participants were randomly assigned to one vignette (Table 1). ${ }^{2}$ After reading the vignette, participants answered two filter questions assessing their knowledge about key aspects of the vignette scenario - names of the parents (to check if participants were aware of the parent's gender) and the plot of the vignette (to check if participants had read the vignette). Afterwards, participants evaluated parenting, child behaviour, family environment, social distance and rights for the family described in the vignette. In the end, participants reported their sexual orientation and an open-ended question for comments was provided.

In total, 806 students from the University of Zagreb participated in the study. Those who partially completed the survey (37\%), were not heterosexual and cisgender (12\%) and/or answered the filter questions incorrectly (3\%) were excluded. In the final sample $(\mathrm{N}=392)$ there were $342(87 \%)$ female and $50(13 \%)$ male participants aged 18 to $37(\mathrm{M}=22.69$; SD = 2.43). More than half of the participants studied for a non-helping profession ( $n=230$; e.g. mathematics, chemistry, economy) and the rest for helping professions ( $n=162$; e.g. psychology, social pedagogy, medicine). Participants were mostly from big cities (> 500000 inhabitants; 34\%) and medium-sized cities (10 001 to 100000 inhabitants; 26\%). Only eight participants $(2 \%)$ had children.

2 SurveyGizmo provides IP-based and Cookie-based duplicate protection. In this research we used cookie-based protection to prevent multiple responses from the same participants. However, cookies are set on a specific browser on a specific device. Thus, if a participant accesses the survey from more than one device or browser, s/he would be permitted to enter more than one response. We did not use IP-based duplicate protection because some environments share a single IP address, such as universities and dormitories. 
Table 1. Distribution of participants by vignette condition and participants' sex $(\mathrm{N}=392)$

\begin{tabular}{|c|c|c|c|c|c|c|}
\hline & & \multicolumn{4}{|c|}{ Participants'sex } & \multirow{3}{*}{$\begin{array}{c}\text { Total } \\
f\end{array}$} \\
\hline & & \multicolumn{2}{|c|}{ male } & \multicolumn{2}{|c|}{ female } & \\
\hline & & $f$ & $\%$ & $f$ & $\%$ & \\
\hline \multicolumn{7}{|c|}{ Positive parenting condition } \\
\hline \multirow{2}{*}{$\begin{array}{l}\text { Different-sex } \\
\text { couple }\end{array}$} & Mother & 9 & 18 & 42 & 82 & 51 \\
\hline & Father & 5 & 11 & 39 & 89 & 44 \\
\hline \multirow{2}{*}{$\begin{array}{l}\text { Same-sex } \\
\text { couple }\end{array}$} & Mother & 5 & 12 & 37 & 88 & 42 \\
\hline & Father & 5 & 11 & 41 & 89 & 46 \\
\hline \multicolumn{7}{|c|}{ Negative parenting condition } \\
\hline \multirow{2}{*}{$\begin{array}{l}\text { Different-sex } \\
\text { couple }\end{array}$} & Mother & 2 & 4 & 43 & 96 & 45 \\
\hline & Father & 9 & 15 & 51 & 85 & 60 \\
\hline \multirow{2}{*}{$\begin{array}{l}\text { Same-sex } \\
\text { couple }\end{array}$} & Mother & 12 & 22 & 43 & 78 & 55 \\
\hline & Father & 3 & 6 & 46 & 94 & 49 \\
\hline
\end{tabular}

\subsection{Measures}

Evaluations of parenting, child behaviour, social distance, and rights were adopted from existing scales. Exploratory factor analysis (principal component analysis) was used to examine scale dimensionality; the number of factors was determined using the Guttman-Kaiser criterion and Cattell's scree test.

Participants reported the following sociodemographic characteristics: age, sex (male, female, other), faculty, year of study, size of the place of residence and sexual orientation (asexual, bisexual, heterosexual, homosexual, not identified with sexual orientation, other).

Evaluations of parenting (adapted from Massey, 2007; Massey, Merriwether and Garcia, 2013) included three questions about the evaluation of parenting skills and the reaction of the active parent who disciplined the child in the vignette (e.g. "How would you rate [name]'s parenting skills?"). The answers were anchored on a 7 -point scale ranging from $1=$ "very bad" to $7=$ "very good". The scale was unidimensional and had excellent internal consistency (father: $\lambda=2.74 ; 91 \%$ of variance explained; Cronbach's $\alpha=.95$; mother: $\lambda=2.66,89 \%$ of variance explained; Cron- 
bach's $\alpha=.93)$. The score was the item mean with higher results indicating more favourable evaluations of parenting.

Evaluations of child behaviour (adapted from Massey, 2007) was measured with five items and a 7-point answer scale. Participants assessed causal attributions for the behaviour of the child portrayed in the vignette, rating separately if the child's behaviour was usual, an indicator of serious developmental difficulties, a result of the child's personality traits, age or parents' relationship. As the items did not form a stable factorial structure, they were analysed separately.

Family environment was measured with 5 items adopted from the Family cohesion scale, (Bloom, 1985, cited in Keresteš, 2001) and 5 items adopted from the Family support scale (Vizek-Vidović and Vlahović Štetić, 1998, cited in Keresteš, 2001). Participants were asked to evaluate cohesion (e.g. "Everyone in this family is getting along well") and support (e.g. "Members of this family console each other if they had a bad day") in the family from the vignette on a scale from 1 ("completely not true for this family") to 3 ("completely true for this family"). The score was the item mean with a higher score indicating a more supporting and cohesive family environment. The scale had excellent internal consistency (Cronbach's $\alpha=.93$ ).

Social distance was measured with items adapted from the original Bogardus' (1933) Social Distance Scale. Outdated items and those that were not related to the Croatian context were omitted. The remaining 29 items were translated using back translation and adapted to relate to the family members from the vignette (e.g. "To which degree would you find acceptable to talk with parents from this family?"). In line with using Bogardus' social distance degrees as survey questions (Ivković, 2010; Mather, Jones and Moats, 2017), participants answered to each item on a 5 -point scale ranging from "very unacceptable" (1) "to very acceptable" (5). The scale was unidimensional ( $\lambda=18.80 ; 65 \%$ variance explained) and had excellent internal consistency (Cronbach's $\alpha=.98$ ). All items were recoded so that a higher total result, calculated as a mean score, indicated greater social distance.

Supporting rights (adapted from Huić, Jugović and Kamenov, 2015) were measured with 5 items and a 5-point answer scale (1 = "very unacceptable" to 5 = "very acceptable"). Two factors emerged: a three-item social and labour rights (employment, hospital visits and inheritance) factor $(\lambda=3.17 ; 63 \%$ variance explained; Cronbach's $\alpha=.92$ ) and a two-item family rights (marriage and adoption) factor $(\lambda$ $=1.19 ; 24 \%$ variance explained; $r=.76)$. The score was the item mean for each dimension with a higher result indicating stronger support.

Restaurant scene vignettes (adapted from Massey, 2007; Massey, Merriwether and Garcia, 2013) were centred around two thematic story lines forming two parenting conditions - a positive, where the scene was resolved calmly (Appendix 1) 
and a negative, where the parent showed a negative reaction towards the child (Appendix 2). In both conditions the gender of the active parent that interacts with the child (mother vs father) and family composition (different-sex vs same-sex couple) were varied. The child's gender was not mentioned. These variations resulted in eight possible vignettes. To prevent survey ordering effects, vignettes were randomised and each participant read only one (between-subject design).

\section{RESULTS}

The study design was a $2 \times 2 \times 2$ factorial experimental design with parenting condition (negative vs positive parent's reaction), parent's gender (mother vs father) and family composition (different-sex vs same-sex couple) as independent variables. ${ }^{3}$ A preliminary analysis showed no differences in participants' gender across eight experimental conditions (cf. Table $1 ; \chi^{2}(7)=10.41, p=.167$ ). A three-way multivariate analysis of variance (MANOVA) was conducted for the evaluation of parenting skills, family environment, and social distance (Table 2).

The results showed significant multivariate main effects for the parenting condition (partial $\eta^{2}=.52$ ) and family composition (partial $\eta^{2}=.11$ ), as well as for the interaction of parenting condition and family composition (partial $\eta^{2}=.03$ ). Follow-up ANOVAs were conducted for significant multivariate effects to detect differences in the evaluations of parenting skills, family environment and social distance.

The results showed large effects of the parenting condition on the evaluations of parenting (partial $\eta^{2}=.50$ ) and family environment (partial $\eta^{2}=.27$ ). Regardless of the active parent's gender and family composition, in the positive parenting condition participants evaluated parenting as skilled and appropriate while in the negative the evaluations were significantly worse and below-average (Figure 1). Similarly, regardless of the active parent's gender and family composition, the family environment was evaluated as better in the positive parenting condition than in the negative (Figure 2).

3 The homogeneity of variance was not met for the dependent variables of parenting, social distance and rights. However, the exceeded minimum cell size (20 cases) and the significance of effects withstanding a more stringent alpha level $(\alpha=.025$; Gamst, Meyers and Guarino, 2008) ensured the robustness of the analysis. 
Table 2. Three-way MANOVA for the evaluation of parenting skills, family environment and social distance with subsequent ANOVAs for significant multivariate effects

\begin{tabular}{llll}
\hline & Wilks' Lambda & $F(d f)$ & $p$ \\
\hline (A) Parenting condition & 0.48 & $140.15(3,382)$ & $<.001$ \\
(B) Active parent's gender & 0.99 & $0.22(3,382)$ & .882 \\
(C) Family composition & 0.89 & $17.78(3,382)$ & $<.001$ \\
Interaction A x B & 0.99 & $1.33(3,382)$ & .264 \\
Interaction A x C & 0.97 & $4.49(3,382)$ & .004 \\
Interaction B x C & 0.99 & $0.92(3,382)$ & .432 \\
Interaction A x B x C & 0.99 & $0.32(3,382)$ & .811 \\
\hline Parenting condition & & & $<.001$ \\
Parenting & $\mathrm{n} / \mathrm{a}$ & $387.65(1,384)$ & $<.001$ \\
Family Environment & $\mathrm{n} / \mathrm{a}$ & $143.36(1,384)$ & $<.001$ \\
Social distance & $\mathrm{n} / \mathrm{a}$ & $56.31(1,384)$ & .358 \\
\hline Family composition & & & .769 \\
Parenting & $\mathrm{n} / \mathrm{a}$ & $0.85(1,384)$ & .0011 \\
Family Environment & $\mathrm{n} / \mathrm{a}$ & $0.09(1,384)$ & .887 \\
Social distance & $\mathrm{n} / \mathrm{a}$ & $26.14(1,384)$ & .001 \\
\hline Interaction A x C & & $0.60(1,384)$ & \\
Parenting & $\mathrm{n} / \mathrm{a} / \mathrm{a} / \mathrm{a}$ & & \\
Family Environment & & $0.02(1,384)$ & \\
Social distance & & $0.33(1,384)$ & \\
\hline
\end{tabular}


Figure 1. Evaluation of parenting by vignette scenario

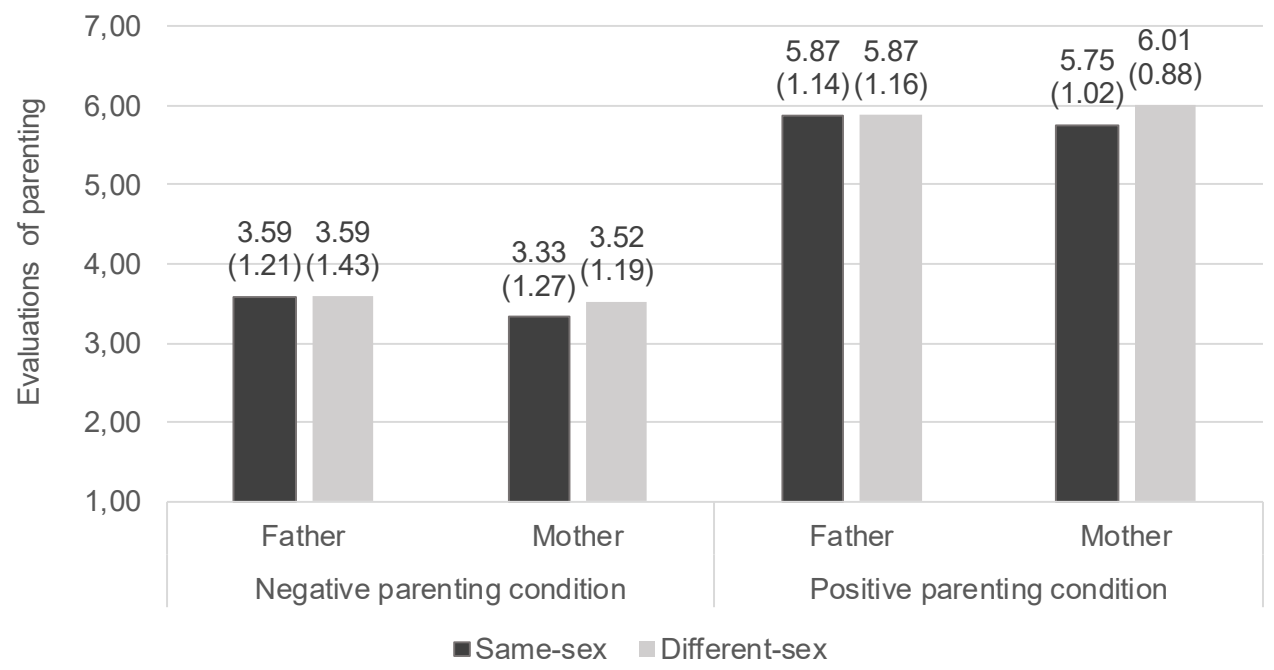

Note: means are indicated above the bars with standard deviation in the brackets

Figure 2. Evaluation of family environment by vignette scenario

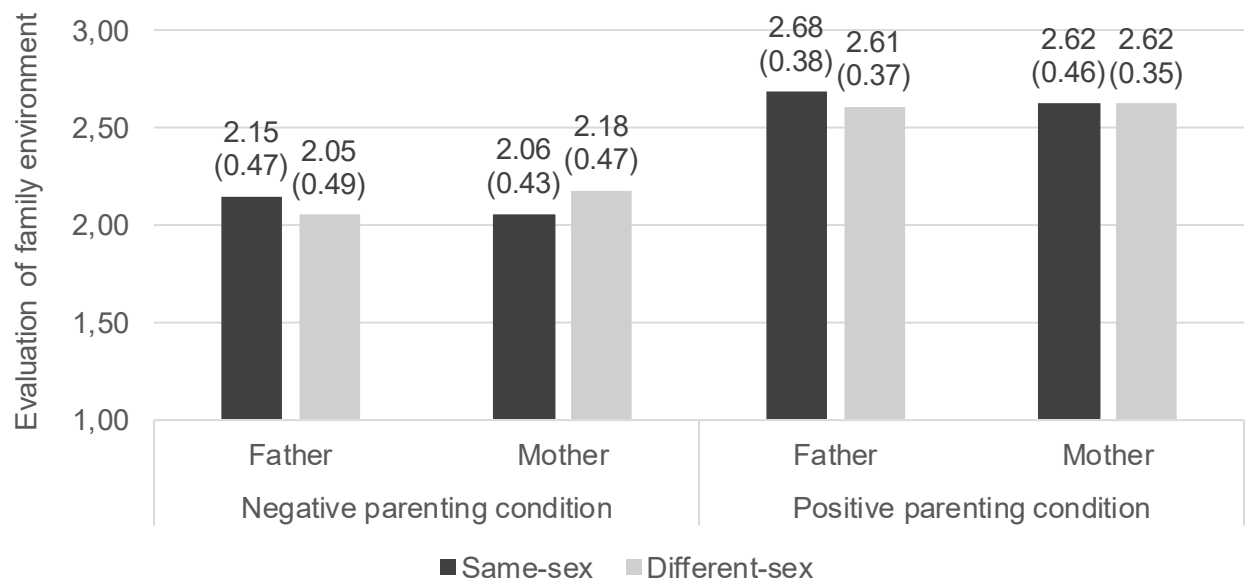

Note: means are indicated above the bars with standard deviation in the brackets 
Overall, evaluations of social distance were below-average suggesting rather small social distance towards family members in all the vignette scenarios (Figure 3). ANOVA results showed a large effect of the parenting condition (partial $\eta^{2}=.13$ ), medium effect of family composition (partial $\eta^{2}=.06$ ) and a significant interaction of the two (partial $\eta^{2}=.02$; Table 2). In other words, in both parenting conditions the social distance was lower for same-sex than different-sex couples, but in the positive parenting condition that effect was lower $(t(181)=2.03 ; p=.044$; Cohen's $d=.30)$ in comparison to the negative parenting condition $(t(207)=5.31 ; p<.001$; Cohen's $d=.73$ ).

Figure 3. Evaluation of social distance by vignette scenario

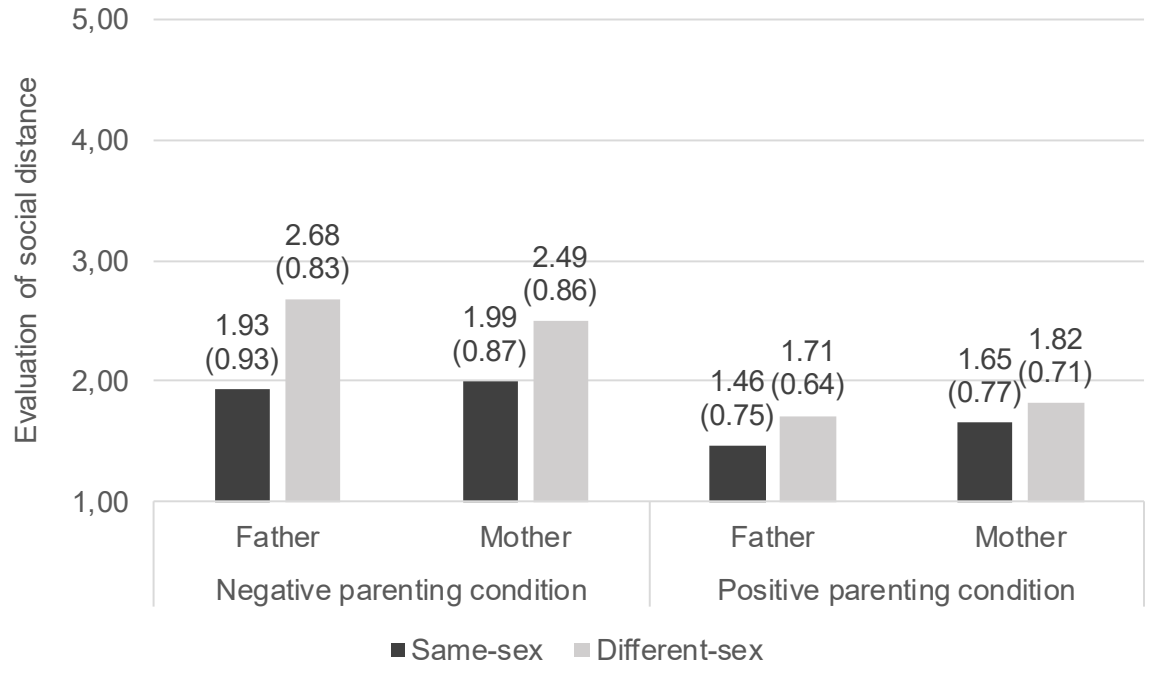

Note: means are indicated above the bars with standard deviation in the brackets

A three-way MANOVA was conducted for the evaluations of child behaviour (Table 3). The results showed a small but significant multivariate main effect only for the parenting condition (partial $\eta^{2}=.03$ ). Follow-up ANOVAs were conducted to detect differences in the evaluations of child behaviour. A small main effect of the parenting condition was significant only for the parents' relationship as the source of child behaviour (partial $\eta^{2}=.01$ ). In the negative parenting condition participants were more likely to evaluate child behaviour as a symptom of parents' relationship than in the positive parenting condition (Table 4). 
Table 3. Three-way MANOVA for child behaviour and ANOVAs for each child behaviour evaluation by parenting condition

\begin{tabular}{lccc}
\hline & $\begin{array}{c}\text { Wilks' } \\
\text { Lambda }\end{array}$ & $F(d f)$ & $p$ \\
\hline Child behaviour & & & \\
(A) Parenting condition & 0.97 & $2.42(5,380)$ & .035 \\
(B) Active parent's gender & 0.98 & $1.21(5,380)$ & .302 \\
(C) Family composition & 0.99 & $0.69(5,380)$ & .634 \\
Interaction A x B & 0.99 & $1.05(5,380)$ & .389 \\
Interaction A x C & 1.00 & $0.34(5,380)$ & .891 \\
Interaction B x C & 0.98 & $1.22(5,380)$ & .301 \\
Interaction A x B x C & 0.98 & $1.67(5,380)$ & .140 \\
\hline Parenting condition & & & \\
Common behaviour & n/a & $0.02(1,384)$ & .891 \\
Developmental problem & n/a & $0.11(1,384)$ & .739 \\
Personality & n/a & $1.82(1,384)$ & .178 \\
Age & n/a & $2.17(1,384)$ & .142 \\
Parents' relationship & n/a & $5.48(1,384)$ & .020 \\
\hline
\end{tabular}


Table 4. Descriptive statistics for evaluations of child behaviour

\begin{tabular}{|c|c|c|c|c|c|c|c|c|}
\hline & \multicolumn{4}{|c|}{ Positive parenting condition } & \multicolumn{4}{|c|}{ Negative parenting condition } \\
\hline & \multicolumn{2}{|c|}{$\begin{array}{l}\text { Different-sex } \\
\text { couple }\end{array}$} & \multicolumn{2}{|c|}{$\begin{array}{c}\text { Same-sex } \\
\text { couple }\end{array}$} & \multicolumn{2}{|c|}{$\begin{array}{c}\text { Different-sex } \\
\text { couple }\end{array}$} & \multicolumn{2}{|c|}{$\begin{array}{c}\text { Same-sex } \\
\text { couple }\end{array}$} \\
\hline & Mother & Father & Mother & Father & Mother & Father & Mother & Father \\
\hline \multicolumn{9}{|c|}{ Common behaviour ${ }^{\text {a }}$} \\
\hline M & 5.14 & 5.52 & 5.14 & 5.57 & 5.53 & 5.23 & 5.29 & 5.39 \\
\hline SD & 1.50 & 1.44 & 1.41 & 1.43 & 1.23 & 1.33 & 1.41 & 1.29 \\
\hline \multicolumn{9}{|c|}{ Developmental problem ${ }^{\mathrm{b}}$} \\
\hline M & 2.16 & 2.02 & 2.17 & 1.98 & 2.02 & 2.03 & 2.36 & 1.73 \\
\hline SD & 1.26 & 1.17 & 1.36 & 1.48 & 1.32 & 1.13 & 1.38 & 0.93 \\
\hline \multicolumn{9}{|c|}{ Personality ${ }^{\mathrm{b}}$} \\
\hline M & 3.78 & 3.77 & 3.71 & 3.67 & 4.18 & 3.63 & 3.76 & 4.22 \\
\hline SD & 1.54 & 1.54 & 1.27 & 1.61 & 1.67 & 1.55 & 1.53 & 1.69 \\
\hline \multicolumn{9}{|l|}{ Age $^{\mathrm{b}}$} \\
\hline M & 5.71 & 5.27 & 5.45 & 5.78 & 5.20 & 5.13 & 5.42 & 5.59 \\
\hline SD & 1.14 & 1.45 & 1.58 & 1.26 & 1.74 & 1.69 & 1.41 & 1.22 \\
\hline \multicolumn{9}{|c|}{ Parents' relationship ${ }^{\mathrm{b}}$} \\
\hline$M$ & 2.67 & 2.45 & 2.71 & 2.48 & 3.24 & 2.92 & 3.04 & 2.65 \\
\hline SD & 1.57 & 1.28 & 1.73 & 1.70 & 1.82 & 1.45 & 1.73 & 1.59 \\
\hline
\end{tabular}

Note: response options: a 1 = "unusual" to 7 = "very usual"; b 1 = "very unlikely" to 7 = "very likely"

Regardless of the parenting condition, active parent's gender or family composition, participants mostly thought that the child's behaviour was common and age-appropriate. Further, they were not inclined to consider the child's behaviour as a result of developmental problems and were undecided about personality as the source of the child's behaviour.

A three-way MANOVA was conducted for willingness to support social, labour and family rights (Table 5). A significant medium multivariate effect was detected for the parenting condition (partial $\eta^{2}=.06$ ) and family composition (partial $\eta^{2}=.06$ ). 
Table 5. Three-way MANOVA for rights and subsequent ANOVAs for each group of rights by parenting condition and family composition

\begin{tabular}{lccc}
\hline & $\begin{array}{c}\text { Wilks' } \\
\text { Lambda }\end{array}$ & $F(d f)$ & $p$ \\
\hline Rights & & & \\
(A) Parenting condition & .94 & $12.62(2,383)$ & $<.001$ \\
(B) Active parent's gender & .99 & $0.96(2,383)$ & .386 \\
(C) Family composition & .94 & $13.04(2,383)$ & $<.001$ \\
Interaction A x B & .99 & $0.31(2,383)$ & .731 \\
Interaction A x C & .99 & $0.55(2,383)$ & .580 \\
Interaction B x C & .99 & $0.33(2,383)$ & .720 \\
Interaction A x B x C & .99 & $0.29(2,383)$ & .746 \\
\hline Parenting condition & & & \\
Labour and social rights & n/a & $3.45(1,384)$ & .064 \\
Family rights & n/a & $27.61(1,384)$ & $<.001$ \\
\hline Family composition & & & \\
Labour and social rights & n/a & $3.45(1,384)$ & .064 \\
Family rights & n/a & $25.16(1,384)$ & $<.001$ \\
\hline
\end{tabular}

Follow-up ANOVAs were conducted to detect differences in participants' standpoints about groups of rights. The results showed a medium effect of the parenting condition (partial $\eta^{2}=.07$ ) and family composition (partial $\eta^{2}=.06$ ) on participants' willingness to grant family rights, while no differences were found for labour and social rights. Participants were more likely to grant family rights to parents in the positive than in the negative parenting condition and to different-sex couples than same-sex couples (Figure 4 and 5). However, in total, the willingness to grant family rights was above-average in all experimental conditions. 
Figure 4. Willingness to grant social and labour rights by vignette scenario

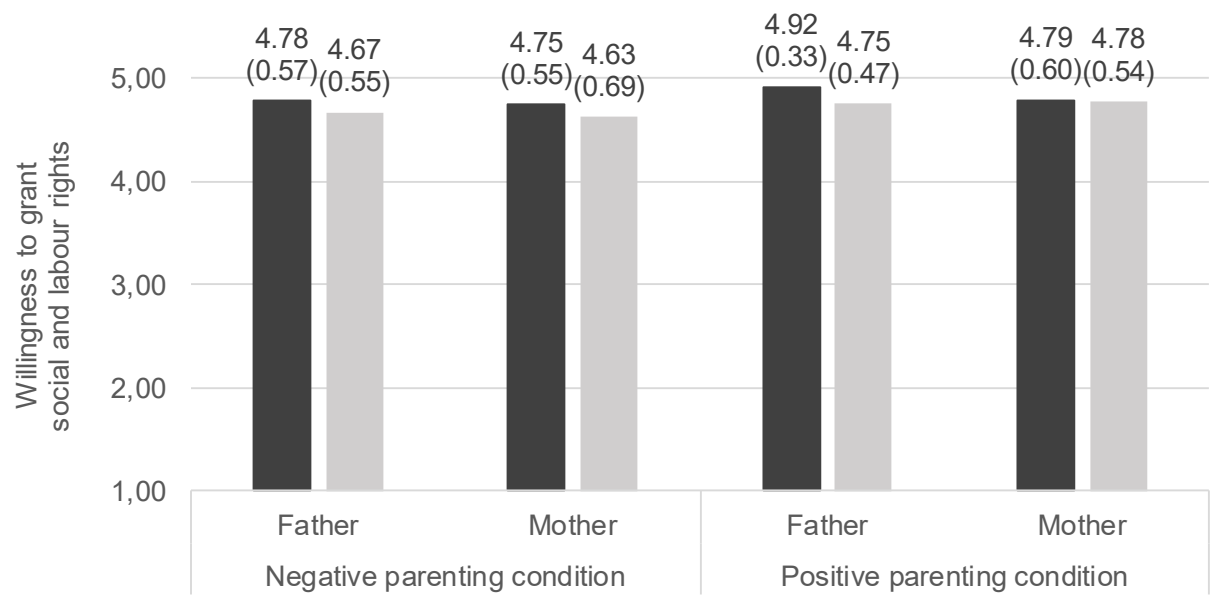

- Same-sex couple Different-sex couple

Note: means are indicated above the bars with standard deviation in the brackets

Figure 5. Willingness to grant family protection rights by vignette scenario

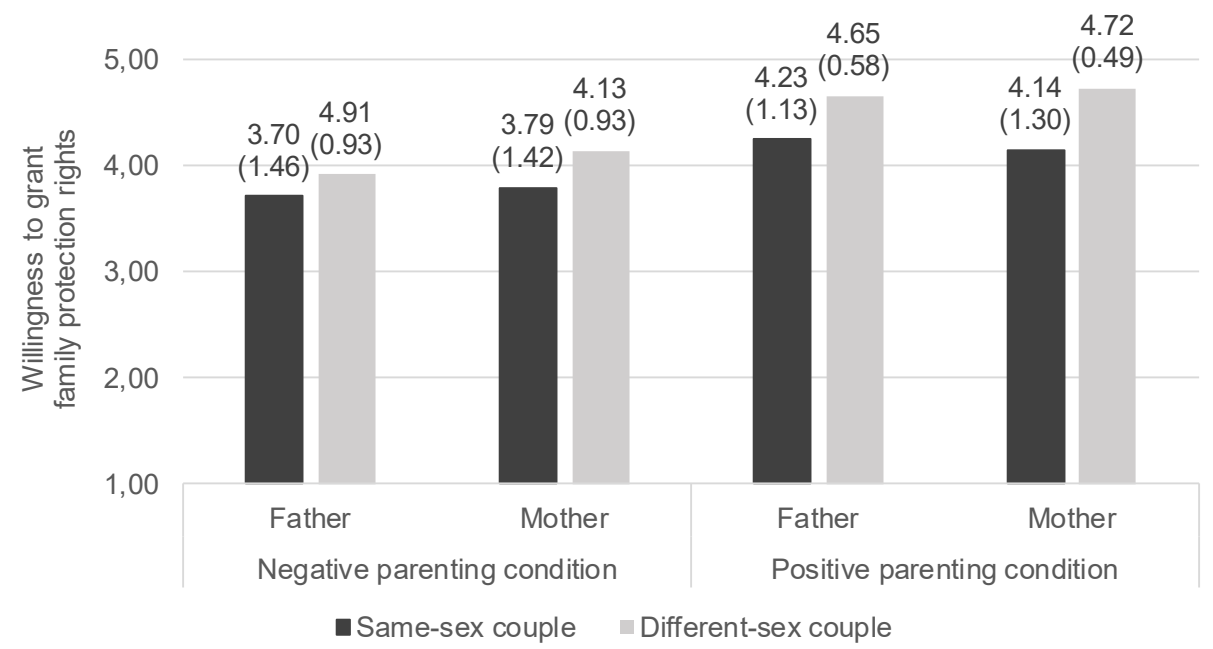

Note: means are indicated above the bars with standard deviation in the brackets 
In summary, our results showed that although participants mostly did not show biased evaluations of same-sex couples' parenting, child's behaviour, and family environment, and showed lower social distance than towards different-sex parents, they favoured different-sex parents when it came to the rights regarding marriage and adoption.

\section{DISCUSSION}

In this study, parenting condition, active parent's gender, and family composition were varied using a between-subjects vignette design to test differences in the evaluations of parenting, child behaviour, family environment, social distance and willingness to grant rights. In line with our expectations, the results showed significant effects of the parenting condition. Family environment and parenting were evaluated as better, participants were less convinced that the child's behaviour was the result of parents' relationship and the social distance was lower in the positive parenting condition than in the negative. Also, participants were more inclined to grant family rights to parents in the positive than in the negative parenting condition. In contrast to our expectation, social distance was lower towards same-sex in comparison to different-sex couples. Finally, although other results suggested mostly unbiased attitudes towards same-sex couples, participants were less inclined to grant family rights to same-sex couples than to different-sex couples.

\subsection{Effects of family composition}

The findings of unbiased evaluations of same-sex couples and a lower social distance towards their families are not in line with the negative stereotypes found in previous studies (Clarke, 2001; Patterson, 2000). However, our results are similar to those found on student samples using vignettes to examine attitudes towards same-sex parents, where differences were either not significant (Massey, Merriwether and Garcia, 2013) or evaluations were more positive for same-sex parents (Massey, 2007). These findings could be attributed to liberal attitudes usually found among students as well as their knowledge about difficult circumstances under which lesbians/gays raise children. Also, the student population is frequently exposed to various groups of people which can make them more willing to accept diversity. Accordingly, Arënliu, Bërxulli and Haskuka (2013) found a decrease in social distance related to more years in education. Thus, it is possible that Croatian students who participated in the study were probably rather liberal and aware of the aggravating circumstances for lesbian/gay parents and their children. This 
could have directed their opinions towards tolerance for same-sex parents and their child's behaviour. It is noteworthy that in our sample most of the participants were female. That could be another origin of unbiased results towards same-sex parents. In general, men show more negative attitudes towards same-sex parenting and marriage than women (loverno et al., 2017; Moskovitz, Rieger and Rolloff, 2010).

In contrast to the unbiased and positively directed evaluations regarding parenting, child's behaviour, and social distance, our participants were less inclined to grant family rights to same-sex than to different-sex parents. This finding suggests that even liberal individuals who will not evaluate specific same-sex parents negatively will not generalise those unbiased attitudes and equally support the preconditions for others to become parents as well, regardless of their sexual orientation. The assumption that for same-sex couples, parenting and marriage are "the straw that breaks the camel's back" is further corroborated with no difference found for other rights - such as those regarding social and labour issues. Social and labour rights are related exclusively to adults, while family rights include children's lives. These results reflect the experiences of existing LGB parented families in Croatia who encounter positive reactions in schools, kindergartens or neighbours at a micro-level (Maričić et al., 2016), but the dominant climate remains anti-samesex parenting (Huić, Jugović and Kamenov, 2015; Kamenov, Huić and Jelić, 2019; Takács and Szalma, 2013). Another explanation for these results is also possible. Considering the homophobic climate in Croatia, participants could have shown less support for family rights because they anticipated harder life circumstances for the children who are adopted by gay/lesbian parents.

It is possible that we have not found biased evaluations of child traits because in this study participants only reported attitudes about a specific behaviour described in the vignette. However, it is possible that some differences would emerge if we had measured other aspects of child development, particularly those that are typically subjected to prejudice such as a child's sexual identity and orientation. Previous research showed that participants expected a lower probability of normative sexual and gender identity of the children adopted by same-sex couples in comparison to those adopted by different-sex couples (Gato and Fontaine, 2013, 2016). Also, in a study by McLeod et al. (1999), participants perceived a gay father as having more positive qualities compared to a heterosexual father, but they still expected non-normative sexual and gender development of his adopted son. 


\subsection{Effects of parenting condition and active parent's gender}

Corporal punishment is considered less appropriate for age-related misbehaviour than for disrespectful behaviour violating strongly held norms (Flynn, 1998). In our study the child's behaviour was evaluated as age-appropriate and, expectedly, our results showed that family members were less favourably evaluated in the negative than in the positive parenting condition. The vignette story was developed to show inappropriate and appropriate parent reaction (corporal punishment vs calming and comforting), but there was no mention of how usual this parent's behaviour was. Massey (2007) argued that the lack of knowledge about children's behaviour can shape the attributions of observers in different directions. Significant differences found in our study suggest that participants generalised the observed parent's reaction and predicted it was usual for the parent in question. In other words, we can argue that participants attributed the parent's reaction as internal, stable and controllable since they showed negative evaluations of the family environment, more social distance and less willingness to grant family rights to the parents in the negative conditions. This result is also in line with the correspondence bias (Gilbert and Malone, 1995). That is, our results could be interpreted in terms of a participant's tendency to draw inferences about a person's dispositions from an isolated behaviour that could be explained by the situation as well.

In this study, participants did not evaluate parents differently regarding their gender - neither different-sex couples nor same-sex couples. For different-sex couples, this result is in line with students' liberal attitudes. Students, as a young and liberal population, can have more egalitarian views on the division of parenting obligations and roles of mothers and fathers. As for same-sex couples, no difference between gays and lesbians is somewhat unexpected. However, our sample mainly consists of female students and previous research showed that among females there is no difference in attitudes towards gays vs lesbians, while men have more negative attitudes towards gays than lesbians (LaMar and Kite, 1998). Also, other studies did not find differences in attitudes towards lesbians vs gays as parents (Gato \& Fontaine, 2013, 2016). Finally, the lack of difference could have resulted from the anticipation of discriminatory treatment for children based on the equally homophobic climate towards lesbian mothers and gay fathers in Croatia.

\subsection{Limitations and future research}

Several limitations apply to the present research. First, as expected in on-line research, male participants were underrepresented. A high proportion of female participants could have shifted the results to more positive evaluations of same-sex 
parents. More even proportions of male to female participants and a larger sample would allow for the introduction of participant's gender as an additional independent variable proven relevant in previous research (Gato and Fontaine, 2016).

Second, previous research indicated that students from Zagreb and Rijeka had more positive attitudes towards LGB people than students from other parts of Croatia (Parmač, 2005). Since our research was conducted among students in Zagreb, future research should include students from different parts of Croatia. Further insight could be gained by tailoring a large and diverse study sample to allow for the introduction of additional independent variables regarding study participants, e.g. a comparison of students of helping and non-helping professions or students coming from urban and rural backgrounds.

Third, on-line research offers more privacy than the paper-pencil approach and can be useful in limiting the influence of social desirability (e.g. Ward et al., 2012). However, on-line research based on the snowball sampling technique results in non-representative samples. Future research would benefit from counterbalancing the advantages and disadvantages of these two data collection techniques to ensure a more representative sample and non-threatening conditions for participation (e.g. by using probability-based online panels).

As indicated in previous studies, there are several promising venues to expand the research on this topic. Our understanding of attitudes towards same-sex parenting would benefit from including additional dependent variables - different aspects of parenting (e.g. couple stability, concerns about abuse), child development (e.g. gender identity, sexual orientation) and wider social environment (e.g. bullying, negative social reactions) - as well as independent variables (e.g. age and gender of the child). Regarding the study sample, it is important to extend participants to the general population, but also to some specific populations like professionals who work with children and LGB parents or make important decisions for these families, such as psychologists and social workers. Finally, in future research, a vignette story could be outlined indicating different family formation methods in order to identify possible differences in participants' attitudes toward same-sex couples who become parents in different ways (adoption, assisted reproductive technologies, surrogacy, etc.)

\section{CONCLUSION AND IMPLICATIONS}

Our study showed that students noticed the parents' inappropriate behaviour in the negative vignette and shifted their judgments accordingly. Furthermore, students' evaluations were unbiased regarding the parents' gender and mostly unbiased regarding family composition. The only differences regarding family composition 
were, unexpectedly, less social distance and, expectedly, less willingness to grant family rights to same-sex couples than to different-sex couples. In other words, although participants mostly had unbiased or positive evaluations of same-sex couples' families, they nevertheless favoured different-sex parents when considering the rights regarding marriage and adoption.

A possible explanation of these results important for the study implications is that the individual example of the same-sex parented family from the vignette may have been interpreted as an exception, an isolated case, which allowed the stability of the biased attitudes towards the group as a whole. This resistance to generalise positive attitudes from individual examples to the whole group is one of the important mechanisms underlying the stability of prejudices and a serious obstacle to challenging inequalities in society. Collective action research points out that the majority/advantaged group can play a crucial role in instigating a profound social change for the minority/disadvantaged group. Majority members usually have more social power and are more persuasive than the minority (Mallett et al., 2008). Certain emotions (guilt, anger or empathy), perspective-taking and recategorisation to a superordinate category with a common goal can lead to the mobilisation of members of advantaged groups for actions that could help disadvantaged groups (lyer and Leach, 2010; Mallett et al., 2008). One way of using these mechanisms is constant education about the challenging position of LGBT people in society, informing the public about the discrimination LGBT people experience as well as engaging LGBT people in public media to stimulate perspective-taking and empathy among members of advantaged groups.

\section{REFERENCES}

adams $j$ and Light $R$ (2015). Scientific consensus, the law, and same sex parenting outcomes, Social Science Research, 53:300-310. https://doi.org/10.1016/j.ssresearch.2015.06.008

Agadullina ER, Lovakov AV and Malysheva NG (2018). Essentialist beliefs and social distance towards gay men and lesbian women: A latent profile analysis, Psychology and Sexuality, 9 (4): 288-304. https://doi.org/10.1080/19419899.2018.1488764

Anti-Discrimination Act (2008). Official Gazette of the Republic of Croatia, 85. https://www. legislationline.org/documents/id/16572

Arënliu A, Bërxulli D and Haskuka M (2013). Social distance in terms of demographic features - Kosovo population study, Iliria International Review, 3 (1): 293-306. https:// doi.org/10.21113/iir.v3i1.113

Assisted Reproductive Technologies Act (2012). Official Gazette of the Republic of Croatia, 116. https://www.zakon.hr/z/248/Zakon-o-medicinski-pomognutoj-oplodnji

Atzmüller C and Steiner PM (2010). Experimental vignette studies in survey research, Methodology, 6 (3): 128-138. https://doi.org/10.1027/1614-2241/a000014 
Ball C (2012). The right to be parents: LGB families and the transformation of parenthood. New York: New York University Press.

Baumle A and D'Lane C (2017). Legalizing LGB families: How the law shapes parenthood. New York: New York University Press.

Bogardus ES (1925). Measuring Social Distance, Journal of Applied Sociology, 9: 299-308.

Bogardus ES (1933). A Social Distance Scale, Sociology and Social Research, 17: 265-271.

Carroll A and Robotham G (2017). Minorities Report 2017: Attitudes to sexual and gender minorities around the world. Geneva: ILGA

Clarke V (2001). What about the children? Arguments against lesbian and gay parenting, Women's Studies International Forum, 24 (5): 555-570. https://doi.org/10.1016/S02775395(01)00193-5

Costa PA and Tasker F (2018). "We wanted a forever family": Altruistic, individualistic, and motivated reasoning motivations for adoption among LGBTQ individuals, Journal of Family Issues, 39 (18): 4156-4178. https://doi.org/10.1177/0192513X18810948

Crowl A, Ahn S and Baker J (2008). A meta-analysis of developmental outcomes for children of same-sex and heterosexual parents, Journal of GLBT Family Studies, 4 (3), 385-407. https://doi.org/10.1080/15504280802177615

Downing, JB (2013). Transgender-parent families. In: Goldberg AE and Allen KR (eds). LGBT-Parent families: Innovations in research and implications for practice. New York: Springer, 105-115. https://doi.org/10.1007/978-1-4614-4556-2_7

Erikson E (1959). Identity and the life cycle: Selected papers, Psychological Issues, 1: $1-171$.

Flaks DK, Ficher I, Masterpasqua F and Joseph G (1995). Lesbians choosing motherhood: A comparative study of lesbian and heterosexual parents and their children, Developmental Psychology, 31 (1): 104-114. https://doi.org/10.1037/0012-1649.31.1.105

Flynn CP (1998). To Spank or Not To Spank: The Effect of Situation and Age of Child on Support for Corporal Punishment, Journal of Family Violence, 13 (1): 21-37. https://doi. org/10.1023/A:1022808716048

Foster Care Act (2018). Official Gazette of the Republic of Croatia, 115. https://narodnenovine.nn.hr/clanci/sluzbeni/2018_12_115_2240.html

Gamst G, Meyers L and Guarino A (2008). Analysis of variance designs: A conceptual and computational approach with SPSS and SAS. New York: Cambridge University Press.

Gato J and Fontaine AM (2013). Anticipation of the sexual and gender development of children adopted by same-sex couples, International Journal of Psychology, 48 (3): 244-253. https://doi.org/10.1080/00207594.2011.645484

Gato J and Fontaine AM (2016). Attitudes toward adoption by same-sex couples: Effects of gender of the participant, sexual orientation of the couple, and gender of the child, Journal of GLBT Family Studies, 12 (1): 46-67. https://doi.org/10.1080/1550428X.2015.1049771

Gilbert D and Malone P (1995). The correspondence bias, Psychological Bulletin, 117 (1): 21-38. https://doi.org/10.1037/0033-2909.117.1.21

Golombok S, Perry B, Burston A, Murray C, Mooney-Somers J, Stevens M and Golding J (2003). Children with lesbian parents: A community study, Developmental Psychology, 39 (1): 20-33. https://doi.org/10.1037/0012-1649.39.1.20

Hughes R (1998). Considering the vignette technique and its application to a study of drug injecting and HIV risk and safer behaviour, Sociology of Health and IIIness, 20 (3): 381400. https://doi.org/10.1111/1467-9566.00107 
Huić A, Jelić M and Kamenov Ž (2018). Essentialist Beliefs About Homosexuality Predict Positive and Negative Behavioral Intentions Toward Lesbian Women and Gay Men, Journal of Homosexuality, 62 (12): 1631-1655. https://doi.org/10.1080/00918369.201 7.1383104

Huić A, Jugović I and Kamenov Ž (2015). Stavovi studenata o pravima osoba homoseksualne orijentacije, Revija za socijalnu politiku, 22 (2): 219-245. https://doi.org/10.3935/rsp. v22i2.1224

Inheritance Act (2019). Official Gazette of the Republic of Croatia, 14. https://www.zakon. $\mathrm{hr} / \mathrm{z} / 87 /$ Zakon-o- nasljeđivanju

loverno S, Carone N, Lingiardi V, Nardelli N, Pagone P, Pistella J, Salvati M, Simonelli A and Baiocco R (2017). Assessing Prejudice Toward Two-Father Parenting and Two-Mother Parenting: The Beliefs on Same-Sex Parenting Scale, The Journal of Sex Research, 55 (4-5): 654-665. https://doi.org/10.1080/00224499.2017.1348460

Ivković Ž (2010). Revizija Bogardusove skale socijalne distance [Revision of the Bogardous Social distance scale]. Unpublished graduate thesis. Zagreb: Faculty of Humanities and Social Sciences.

Iyer A and Leach CW (2010). Helping disadvantaged out-groups challenge unjust inequality: The role of group-based emotions. In: Stefan S and Mark S (eds). The psychology of prosocial behavior: Group processes, intergroup relations, and helping. New Jersey: Wiley-Blackwell, 337-353. https://doi.org/10.1002/9781444307948.ch17

Jugović I and Ogresta J (2017). "The problem is the reactions of the social environment": Young people's opinion about the parenthood of same-sex couples. In: Ćubela Adorić V, Franc R, Kalebić Maglica B and Nakić Radoš S (eds). 25. godišnja konferencija hrvatskih psihologa: psihologija u promociji i zaštiti ljudskih prava i društvene pravednosti - sažetci priopćenja. Zadar: Hrvatsko psihološko društvo, 54-54. https://www.bib.irb.hr/919002

Kamenov Ž, Huić A and Jelić M (2019). Attitudes towards Gay and Lesbian Parental Rights among Heterosexual Croatian Citizens: The Effect of Traditional Gender-Role Attitudes, Croatian Sociological Review, 49 (2): 231-251. https://doi.org/10.5613/rzs.49.2.5

Keresteš G (2001). Roditeljsko ponašanje i obiteljska klima u obiteljima samohranih majka [Parental Behaviour and Family Atmosphere in Self-Supporting Mothers' Families], Društvena istraživanja, 10 (4-5): 903-925.

LaMar L and Kite M (1998). Sex differences in attitudes toward gay men and lesbians: A multidimensional perspective, The Journal of Sex Research, 35 (2): 189-196. https://doi. org/10.1080/00224499809551932

Mallett RK, Huntsinger JR, Sinclair S and Swim JK (2008). Seeing through their eyes: When majority group members take collective action on behalf of an outgroup, Group Processes \& Intergroup Relations, 11 (4): 451-470. https://doi.org/10.1177/1368430208095400

Maričić A, Štambuk M, Tadić Vujčić M and Tolić S (2016). Ja nisam gej mama, ja sam mama: roditeljstvo LGB osoba u Hrvatskoj II'm not a gay mom, I'm a mom. Parenthood of LGB people in Croatia]. Zagreb: Jesenski i Turk.

Massey SG (2007). Sexism, Heterosexism, and Attributions about Undesirable Behavior in Children of Gay, Lesbian, and Heterosexual Parents, Journal of GLBT Family Studies, 3 (4): 457-483. https://doi.org/10.1300/J461v03n04_05

Massey SG, Merriwether AM and Garcia JR (2013). Modern prejudice and same-sex parenting: Shifting judgments in positive and negative parenting situations, Journal of GLBT Family Studies, 9 (2): 129-151. https://doi.org/10.1080/1550428X.2013.765257 
Mather DM, Jones SW and Moats S (2017). Improving upon Bogardus: Creating a More Sensitive and Dynamic Social Distance Scale, Survey Practice, 10 (4): 1-10. https://doi. org/10.29115/SP-2017-0026

McLeod AC, Crawford I and Zechmeister J (1999). Heterosexual Undergraduates' Attitudes toward Gay Fathers and their Children, Journal of Psychology \& Human Sexuality, 11 (1): 43-62. https://doi.org/10.1300/J056v11n01_03

Morrison MA, Morrison TG and Franklin R (2009). Modern and old-fashioned homonegativity among samples of Canadian and American university students, Journal of Cross-Cultural Psychology, 40 (4): 523-542. https://doi.org/10.1177/0022022109335053

Morse CN, McLaren S and McLachlan AJ (2008). The Attitudes of Australian Heterosexuals toward Same-Sex Parents, Journal of GLBT Family Studies, 3 (4): 425-455. https://doi. org/10.1300/J461v03n04_04

Moskowitz DA, Rieger G and Roloff ME (2010). Heterosexual Attitudes toward Same-Sex Marriage, Journal of Homosexuality, 57 (2): 325-336. https://doi. org/10.1080/00918360903489176

Parmač M (2005). Stavovi studenata prema osobama homoseksualne orijentacije [Student attitudes towards people with a homosexual orientation]. Unpublished graduate thesis. Zagreb: Faculty of Humanities and Social Sciences.

Patterson CJ (2000). Family Relationships of Lesbian and Gay Men, Journal of Marriage and the Family, 62 (4): 1052-1069. https://doi.org/10.1111/j.1741-3737.2000.01052.x

Peruzzi N (2015). Zločini iz mržnje prema LGBT osobama: zakoni za primjer, provedba u praksi daleko od toga. Crol, 16 November. https://www.crol.hr/index.php/politikaaktivizam/7158-zlocini-iz-mrznje-prema-lgbt-osobama-zakoni-za-primjer-provedba-upraksi-daleko-od-toga (19 June 2019)

Protocol for Medical Documents Collection and Determination of the Conditions and Prerequisites for Sex Change or Life in Different Gender Identity (2014). Official Gazette of the Republic of Croatia, 132.

Roberts SO, Ho AK, Rhodes M and Gelman SA (2017). Making boundaries great again: Essentialism and support for boundary-enhancing initiatives, Personality and Social Psychology Bulletin, 43 (12): 1643-1658. https://doi.org/10.1177/0146167217724801

Same-Sex Civil Union Act (2003). Official Gazette of the Republic of Croatia, 116.

Same-Sex-Life-Partnership Act (2014). Official Gazette of the Republic of Croatia, 92. http:// www.zivotnopartnerstvo.com/wp-content/uploads/2015/06/same-sex-life-partnershipact-croatia.pdf

Social Welfare Act (2017). Official Gazette of the Republic of Croatia, 130. https://www. zakon.hr/z/222/Zakon-o-socijalnoj-skrbi

Štambuk M, Milković M and Maričić A (2019). Motivation for Parenthood among LGBTIQ People in Croatia: Reasons for (not) Becoming a Parent, Croatian Sociological Review,49 (2): 149-173. https://doi.org/10.5613/rzs.49.2.2

Takács J and Szalma I (2013). How to measure homophobia in an international comparison?, Družboslovne razprave, 29 (2): 11-42.

Vučković Juroš T (2017). Comparing the Outcomes of Children of Same-Sex and Opposite-Sex Partners: Overview of the Quantitative Studies Conducted on Random Representative Samples, Revija za sociologiju, 47 (1): 65-95. https://doi.org/10.5613/ rzs.47.1.3 
Ward P, Clark T, Zabriskie R and Morris T (2012). Paper/pencil versus online data collection: An exploratory study, Journal of Leisure Research, 44 (4): 507-530. https://doi.org/10.1 080/00222216.2012.11950276

Weiner B (1985). An attributional theory of achievement motivation and emotion, Psychological Review, 92 (4): 548-573.

\section{APPENDICES}

Appendix 1: Restaurant scene vignette portraying positive parenting condition, father as the active parent and a same-sex couple

Imagine you are sitting in a restaurant and having dinner. Across the room, [two $m e n]$ are sitting with their four-year-old child. You see the two are holding hands. [One man, Kristijan], hugs [the other man, Danije/], leans over and kisses [him] on the cheek. Then they both take turns talking to the child. The waiter brings them dinner and [Kristijan] puts some food in a colourful bowl for the child. The child looks at the bowl and frowns. Suddenly, the child pushes its bowl away, throws it on the floor and starts screaming - "I don't want that! No! No! No!". People in the restaurant turn their heads to look at them. [Kristijan] picks up the bowl from the floor. He calmly tells the child to stop screaming and to eat the dinner. The child picks up the bowl and tries to throw it back on the floor. [Kristijan] takes the child's hand and asks - "What made you angry?". The child starts crying. [Kristijan] comes closer and hugs the child. The child is still upset but, in a few minutes, starts to calm down. [Danijel] puts a new bowl of food in front of the child and, after some time, the child starts to eat its dinner.

Appendix 2: Restaurant scene vignette portraying negative parenting condition, father as the active parent and a different-sex couple

Imagine you are sitting in a restaurant and having dinner. Across the room, [a man and a woman] are sitting with their four-year-old child. You see the two are holding hands. [A man, Kristijan], hugs [the woman, Danijela], leans over and kisses [her] on the cheek. Then they both take turns talking to the child. The waiter brings them dinner and [Kristijan] puts some food in a colourful bowl for the child. The child looks at the bowl and frowns. Suddenly, the child pushes its bowl away, throws it on the floor and starts screaming - "I don't want that! No! No! No!". People in the restaurant turn their heads to look at them. [Kristijan] picks up the bowl from the floor. In an angry raised voice, he tells the child to stop screaming and to eat the 
dinner. The child picks up the bowl and tries to throw it back on the floor. [Kristijan] smacks the child's hand and yells - "Put that back on the table!". The child starts crying. [Kristijan] needs a couple of minutes to calm the child. It is obvious that [he] is getting more and more frustrated by the child's behaviour, but [he] manages to calm the child down. [Danijela] puts a new bowl of food in front of the child and, after some time, the child starts to eat its dinner. 


\title{
Procjene roditeljstva istospolnih parova u odnosu na roditeljstvo parova različitog spola: primjena vinjeta u složenom eksperimentalnom nacrtu među sveučilišnim studentima $i$ studenticama heteroseksualne orijentacije
}

\author{
Mateo ŠTRBIĆ (D), Tomislav JELEKOVIĆ (D), Dora POPOVIĆ (D), Marija \\ BRAJKOVIĆ (D), Petra ŽUKINA (D) \\ studenti (Odsjek za psihologiju Hrvatskih studija Sveučilišta u Zagrebu, Hrvatska) \\ mateo.strbic@gmail.com, tomislavjelekovic.tj@gmail.com,dora.popovic123@ \\ gmail.com,marijabrajkovic95@gmail.com, petra.zukinax@gmail.com
}

\section{Marina ŠTAMBUK}

Zavod za menadžment i ruralno poduzetništvo Agronomskog fakulteta Sveučilišta u Zagrebu, Hrvatska

mstambuk@agr.hr

\section{SAŽETAK}

Unatoč smanjenju predrasuda prema LGBT osobama, pitanje roditeljstva još je uvijek kontroverzno i negativni stavovi o LGBT roditeljima otvoreno se iznose. Cilj ove studije bio je istražiti stavove prema roditeljstvu istospolnih parova koristeći vinjete. Varirani su bili uvjet roditeljstva (negativna u odnosu na pozitivnu reakciju roditelja), spol aktivnog roditelja (majka u odnosu na oca) i struktura obitelji (istospolni u odnosu na parove različitog spola) kako bi se testirale razlike u procjenama roditeljstva, ponašanja djece, obiteljske klime, društvene distance i spremnosti na priznavanje prava. U internetskom anketnom istraživanju sudjelovalo je 392 studenta/ice Sveučilišta u Zagrebu (87\% ženskog i $13 \%$ muškog spola) u dobi od 18 do 37 godina. Nakon čitanja jedne od osam vinjeta, sudionici/e su procjenjivali roditeljstvo, ponašanje djeteta, obiteljsku klimu, društvenu distancu i prava za članove/ice obitelji opisane u vinjeti. Roditeljstvo i obiteljska klima bili su bolje procijenjeni te su sudionici/e bili manje uvjereni da je dječje ponašanje rezultat roditeljskog odnosa u uvjetu pozitivne roditeljske reakcije u odnosu na negativnu. Društvena distanca bila je manja prema roditeljima u uvjetu pozitivne roditeljske reakcije $u$ odnosu na negativnu i, neočekivano, prema istospolnim u odnosu na parove različitog spola. Sudionici/e su bili spremniji priznati prava vezana uz obitelj roditeljima u uvjetu pozitivne roditeljske reakcije u odnosu na negativnu. lako drugi rezultati nisu pokazali negativnu pristranost prema roditeljstvu istospolnih parova, sudionici/e su bili manje skloni priznati im prava vezana uz obitelj u odnosu na parove različitog spola. Ti nalazi odražavaju važan mehanizam stabilnosti predrasuda - otpor prema generaliziranju stavova od individualnih slučajeva na skupinu i mogu se upotrijebiti pri suzbijanju predrasuda o roditeljstvu LGBT osoba.

Ključne riječi: istospolni parovi, parovi različitog spola, roditeljstvo, ponašanje djece, društvena distanca, prava vezana uz obitelji 
